\title{
Prostat Kanseri Tanısında Kan Nötrofil / Lenfosit Dağılımının Yeri
}

\author{
Role Of Blood Neutrophil / Lymphocyte Distribution In The Diagnosis Of Prostate Cancer
}

\author{
Mehmet Eflatun Deniz', Hakan Erçil², Ergün Alma², Erbay Tümer², Adem Altunkol², Umut Unal², Zafer Gökhan Gürbüz² \\ 1 Adiyaman University, Training and Research Hospital, Adiyaman, Turkey \\ 2 University of Health and Science, Adana City Hospital, Department of Urology, Adana, Turkey
}

Geliş tarihi (Submitted): 11.02.2019 Kabul tarihi (Accepted): 08.08.2019

Yazışma / Correspondence Mehmet Eflatun Deniz Adıyaman Üniversitesi, Eğitim Araştırma Hastanesi, Adıyaman, Merkez, 1164. Sk N:13, 02100 Ziyaretpayamlı/Adıyaman/Türkiye E mail: eflatun7@gmail.com Tel: +904162161015 Gsm: +90 5304079085

\section{ORCID}

M.E.D. 0000-0003-2570-3784

H.E. $\quad 0000-0001-7103-7597$

E.A. $\quad 0000-0003-2633-5274$

E.T. $0000-0002-8135-3312$

A.A. $\quad 0000-0002-9300-3694$

U.U. $\quad 0000-0002-8135-3312$

Z.G.G. 0000-0002-7325-1965

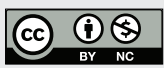

$\mathrm{Bu}$ eser Creative Commons AtıfGayriticari 4.0 Uluslararassı Lisansı ile lisanslanmıștır.

\section{Özet}

Amaç: Nötrofil lenfosit oranı (NLR) son zamanlarda oldukça popüler olan tanısal bir belirteçtir. Bu makalede NLR'nin prostat kanseri tanısındaki yeri, cut off değeri yanında platelet lenfosit oranı (PLR), Gleason skoru ve biyopside saptanan tümör yüzdesi ile ilişkisi değerlendirildi. Ayrıca transrektal ultrason (TRUS) eşliğinde biyopsi yapılan hastaların bulguları paylaşıldı.

Gereç ve Yöntemler: Kliniğimizde 2014 ağustos-2017 şubat tarihlerinde, prostat spesifik antijen (PSA) değerleri $2.5 \mathrm{ng} / \mathrm{ml}$ ve üzeri olup TRUS eşliğinde prostat biyopsisi yapılan 679 hastanın sonuçları retrospektif olarak incelendi. Hastalar PSA değerlerine göre 2.5-3.9 ng/ml aras1 (Grup 1), 4-9.9 ng/ml arası (Grup 2), 10-19.9 $\mathrm{ng} / \mathrm{ml}$ arası (Grup 3), $20 \mathrm{ng} / \mathrm{ml}$ ve üzeri (Grup 4) olarak dört gruba ayrıldı. NLR'nin bu gruplarda patoloji sonuçlarına göre tanısal değeri incelendi.

Bulgular: NLR, grup 2,3 ve 4'te diagnostik bir belirteç olarak bulundu. Cut off değeri 2.5 olarak hesaplandı. PLR ile benzer tanısal güce sahipti. Gleason skoru ve her bir core tümör yüzdesi ile zayıf bir korelasyonu vardı. Kemik metastazını öngörmede bir öneme sahip değildi. PSA dansitesi ve rektal tuşe bulguları arasındaki fark, patolojisi prostat kanseri (PCa) veya benign prostat hiperplazisi (BPH) olan gruplar da istatistiksel olarak anlamlıdı.

Sonuç: NLR PCa tanısında çok güçlü olmasa da diagnostik bir değere sahiptir. PSA' yı destekleyici bir belirteç olarak kullanılabilir.

Anahtar Kelimeler: Nötrofil lenfosit oranı(NLR), Prostat kanseri, tanısal belirteç
Abstract

Objective: Neutrophil to lymphocyte ratio (NLR) is a recently popular diagnostic marker. We sought answers to questions such as whether this marker has a role in the diagnosis of prostate cancer, any cut off value can be calculated, compared to platelet lymphocyte ratio (PLR) and it has a relationship with Gleason score and percentage of tumors detected in biopsy cores. In addition, we aimed to share the findings of patients undergoing transrectal ultrasound (TRUS) guided biopsy.

Materials and Methods: The results of 679 patients who underwent TRUS-guided prostate biopsy with prostate specific antigen (PSA) values above $2.5 \mathrm{ng} / \mathrm{ml}$ in our clinic between $\mathrm{Au}$ gust 2014 and February 2017 were retrospectively analyzed. Patients were between 2.5-3.9 $\mathrm{ng} / \mathrm{ml}$ (Group 1), 4-9.9 ng / ml (Group 2), 10-19.9 ng / $\mathrm{ml}$ (Group 3), $20 \mathrm{ng} / \mathrm{ml}$ and above (Group 4) according to PSA values, divided into four groups. The diagnostic value of NLR was evaluated in these groups.

Results: NLR was found as a diagnostic marker in groups 2,3 and 4. The cut off value was calculated as 2.5. It had similar diagnostic power as PLR. There was a poor correlation with Gleason score and percentage of tumor in cores. It was not important in predicting bone metastasis. The difference between PSA density and DRE was statistically significant in groups with pathologic prostate cancer ( $\mathrm{PCa}$ ) or benign prostatic hyperplasia (BPH).

Conclusion: Although NLR is not very strong in the diagnosis of PCa, it has a diagnostic value. It can be used as a marker to support PSA.

Keywords: Neutrophil lymphocyte ratio (NLR), prostate cancer, diagnostic marker. 


\section{INTRODUCTION}

Prostate cancer $(\mathrm{PCa})$ is a common cancer type in men. A man's risk of getting into PCa for life is one in eight. PCa is the third leading cause of cancer death in men, followed by lung cancer and colorectal cancer. (1)

The number of men with latent PCa ( those present in the prostate gland, but never identified or diagnosed during the life of a patient) is greater than the number of men who are clinically diagnosed with PCa. Some PCa cases follow a silent clinic and some of them are life-threatening. (2)

Today, transrectal ultrasonography (TRUS) guided biopsy is still the gold standard for PCa diagnosis. Approximately, 1 out of 5 men with PCa may have misdiagnosed the first biopsy because of that new markers are needed. In addition to PSA, we need more sensivite and high specific markers.

The relationship between inflammation and cancer is a long-standing debate. Although the detailed mechanism is still unclear, inflammation is thought to play a critical role. Regeneration and excessive proliferation, especially in response to oxidative damage, hypoxia or autoimmunity after inflammation can lead to PCa. Neutrophil to lymphocyte ratio (NLR) is one of the parameters of inflammation and is said to be a crucial prognostic factor in some solid organ cancers such as PCa. (3)

In this study, we investigated the safety and diagnostic value of NLR in different groups that divided by PSA levels.

\section{MATERIALS AND METHODS}

The files of 679 patients who received TRUS-associated prostate biopsy at our clinic between August 2014 and February 2017 were retrospectively examined. Our study was approved by the ethics committee with the decision no. 50 dated 28.3.2017 at Health Science University Adana City Hospital. Patients, between 40 and 75 years old had either a suspicious rectal examination or PSA elevation above $2.5 \mathrm{ng} / \mathrm{ml}$. Before the biopsy, urine culture and whole blood count were obtained. Biopsy was taken from the patients with suspected urinary infection or contaminated urinary culture after the following appropriate antibiotic treatment. Patients using antiagregan drugs stopped their treatment for
5-7 days prior to biopsy. Patients who have any prostate-related intervention, surgery, medical treatment, hematologic diseases that affect blood cells count, any infection or previously prostate biopsy history were excluded from this study.

\section{Patient Preparation}

Patients used rectal laxative enema before the day of procedure. Furthermore, ciprofloxacin $500 \mathrm{mg}$ oral tablets were given nearly 2 hours earlier before the biopsy.

\section{Patient Position and Biopsy}

The prostate biopsy needles are disposable and 18 gauge thick. The patients were laid on examination table on the left lateral decubitus position. After the lidocaine gel and prostatic block were performed before the procedure, the anesthetic effect was waited for ten minutes. A total of 12 core biopsies were obtained from the right and left side by taking two pieces from the prostate basal middle and apex region with the TRUS coexistence.

\section{Post-processing Suggestions}

All patients were observed in the clinic for two hours after the procedure then the patients with good overall condition were discharged and informed to come back to the hospital if fever, constantly hematuria or hematochezia occur. They were called back 3 weeks later for patology results.

\section{Evaluation}

Patients separated into four groups by using their PSA levels. 2.5-3.9 $\mathrm{ng} / \mathrm{ml}$ (Group 1), 4-9.9 ng / ml (Group 2), 10-19.9 ng / ml (Group 3), $20 \mathrm{ng} / \mathrm{ml}$ and above (Group 4). Groups were also divided into benign prostatic hyperplasia(BPH) and $\mathrm{PCa}$ subgroups according to pathologic results. Patients in subgroups were evaluated statistically in terms of blood counts, NLR ratios, prostate volumes, PSA levels and densities.

In addition that, Gleason score and PCa percentage in the cores were statistically analyzed in patients.

\section{Statistical Analysis}

Categorical measurements were summarized as numbers and percentages, besides, numerical measurements were also analyzed as mean and standard 
deviation. Chi-square test statistic was used to compare categorical measurements between groups and ShapiroWilk test was used to test whether the numerical measurements provided the normal distribution assumption. T-test was used to compare numerical measurements between the groups, Pearson correlation was used if the assumptions were met and Spearman correlation was used when the assumptions were not met. The effect of PSA value on the correlation between variables was analyzed by partial correlation analysis. In the diagnosis of $\mathrm{PCa}$, sensitivity, specitifity, positive predictive value, negative predictive value and Kappa statistics were calculated for NLR, platelet to lympho- cyte ratio (PLR), PSA, PSA density, digital rectal examination. IBM SPSS Statistics Version 20.0 package program was used for statistical analysis of the data. Statistical significance was taken as 0.05 in all tests.

SPSS Reference: IBMCorp. Released 2011. IBM SPSS Statistics for Windows, Version 20.0. Armonk, NY: IBM Corp.

\section{RESULTS}

Whether or not NLR had a diagnostic value in the prostate cancer were examined. The results were indicated that there was not any statistical difference between $\mathrm{PCa}$ and BPH patients in the first group, but there was a significant difference in the other groups. (Table 1-4)

Table 1: Patients with PSA between 2.5-4

\begin{tabular}{llll} 
& BPH $(\mathbf{n}=\mathbf{6 3})$ & PCa $(\mathbf{n}=\mathbf{8})$ & P value \\
\hline Neutrophil count & $4,81 \pm 1,64$ & $3,97 \pm 0,89$ & 0,136 \\
Lymphocyte count & $2,17 \pm 0,78$ & $2,63 \pm 1,90$ & 0,892 \\
NLR & $2,40 \pm 1,01$ & $2,21 \pm 1,46$ & 0,408 \\
Age & $57,71 \pm 6,97$ & $59,38 \pm 5,68$ & 0,518 \\
PSA $(\mathbf{n g} / \mathbf{m l})$ & $3,41 \pm 0,40$ & $3,54 \pm 0,27$ & 0,344 \\
Prostate volume $\left(\mathbf{c c}^{\mathbf{3}}\right)$ & $50,84 \pm 16,91$ & $34,38 \pm 9,05$ & 0,003 \\
\hline
\end{tabular}

Note: Mann Whitney $U$ test was used. $n=$ sample size. Significance marked in bold.

Table 2: Patients with PSA between 4-10

\begin{tabular}{llll} 
& BPH $(\mathbf{n}=\mathbf{3 4 4})$ & PCa $(\mathbf{n}=\mathbf{8 0})$ & P value \\
\hline Neutrophil count & $5,12 \pm 2,46$ & $6,08 \pm 3,37$ & 0,005 \\
Lymphocyte count & $2,14 \pm 0,79$ & $2,07 \pm 0,86$ & 0,404 \\
NLR & $2,79 \pm 2,12$ & $3,40 \pm 2,86$ & 0,038 \\
Age & $62,19 \pm 6,96$ & $66,61 \pm 6,97$ & $<0,001$ \\
PSA(ng/ml) & $6,57 \pm 1,78$ & $7,10 \pm 1,86$ & 0,018 \\
Prostate volume $\left(\mathrm{cc}^{\mathbf{3}}\right)$ & $63,05 \pm 29,57$ & $52,99 \pm 25,54$ & 0,001 \\
\hline
\end{tabular}

Note: Mann Whitney $U$ test was used. $n=$ sample size. Significance marked in bold.

Table 3: Patients with PSA between 10-20

\begin{tabular}{llll} 
& BPH $(\mathbf{n}=\mathbf{6 9})$ & PCa $(\mathbf{n}=\mathbf{3 0})$ & P value \\
\hline Neutrophil count & $5,74 \pm 2,63$ & $5,77 \pm 2,00$ & 0,576 \\
Lymphocyte count & $2,00 \pm 0,75$ & $1,67 \pm 0,69$ & 0,020 \\
NLR & $3,71 \pm 4,57$ & $4,03 \pm 2,15$ & 0,036 \\
Age & $63,30 \pm 7,82$ & $68,83 \pm 6,84$ & 0,001 \\
PSA(ng/ml) & $13,69 \pm 1,91$ & $15,37 \pm 2,39$ & 0,001 \\
Prostate volume $\left(\mathrm{cc}^{\mathbf{3}}\right)$ & $76,35 \pm 46,39$ & $57,10 \pm 30,2$ & 0,018 \\
\hline
\end{tabular}

Note: Mann Whitney $U$ test was used. $n=$ sample size. Significance marked in bold. 
Table 4: Patients with PSA of 20 and above

\begin{tabular}{llll} 
& BPH $(\mathbf{n}=\mathbf{2 2})$ & PCa $(\mathbf{n}=\mathbf{6 3})$ & P value \\
\hline Neutrophil count & $5,63 \pm 2,54$ & $6,01 \pm 2,22$ & 0,316 \\
Lymphocyte count & $2,00 \pm 0,49$ & $1,79 \pm 0,81$ & 0,126 \\
NLR & $2,94 \pm 1,53$ & $4,05 \pm 2,38$ & 0,045 \\
Age & $66,14 \pm 8,72$ & $72,54 \pm 7,17$ & 0,004 \\
PSA $(\mathbf{n g} / \mathbf{m l})$ & $35,22 \pm 17,77$ & $208,56 \pm 398,20$ & $<0,001$ \\
Median & $28,84(20,6-100)$ & $55,18(20,2-1952)$ & $<0,001$ \\
\hline Prostate volume $\left(\mathrm{cc}^{\mathbf{3}}\right)$ & $86,41 \pm 81,59$ & $53,49 \pm 22,35$ & $<$ \\
\hline
\end{tabular}

Note: Mann Whitney $U$ test was used. $n=$ sample size. Significance marked in bold.

PSA density calculates by dividing the total PSA by the prostate volume measured in transrectal ultrasound. In this study, the obtained PSA density was significantly higher in patients with PCa than in patients with BPH due to pathology (Table 5)(Figure 1).

In terms of whether there is a relationship between NLR, Gleason score and the percentage of tumors in pathology results, weak positive correlations between NLR, Gleason score and tumor percentage in biopsy cores were found $(\mathrm{p}=0.011$ and $\mathrm{p}=0.025)$. In other words, when NLR increases, Gleason score and tumor percentage slightly increase. When the relationship

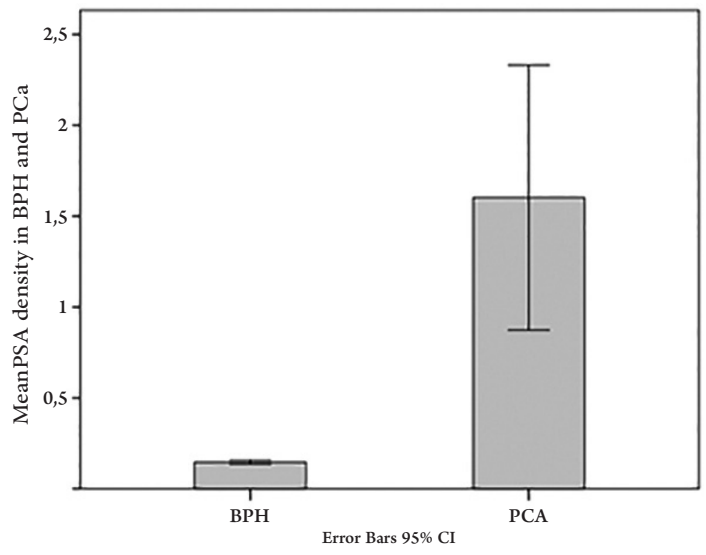

Figur 1. PSA density in $\mathrm{BPH}$ and $\mathrm{PCa}$ among the patient groups were examined, there was a weak positive correlation between NLR and tumor percentage only in the group 2 (due to the relatively large number of patients) $(p=0.016)$. No significant relationship was found in the other groups.

There was a moderately strong positive correlation between Gleason score and tumor percentage $(\mathrm{p}$ $<0.001)$. When Gleason score were increased, the tumor percentage in biopsy cores were increased simultaneously. The correlation level between the Gleason score and tumor percentage is better than the correlation between than the previous one (Figure 2).

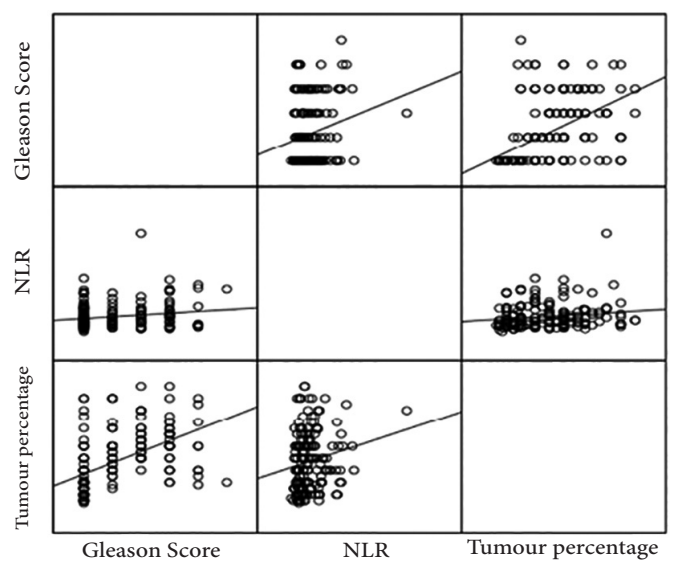

Figur 2. NLR relationship between tumour percentage in biopsy core and Gleason score

Table 5: PSA density values in patients

\begin{tabular}{|c|c|c|c|}
\hline & \multicolumn{2}{|c|}{ Patology results } & \multirow[b]{2}{*}{$P$ value } \\
\hline & ВPH & PCa & \\
\hline PSA density (ng/dl/cc3) & $0,15 \pm 0,13$ & $1,6 \pm 4,97$ & $<0,001$ \\
\hline
\end{tabular}


If cut off value was tested for NLR in the ROC analysis, area under the curve (AUC) was found 0.624. This indicated that the value was not a good marker and the diagnostic ability was low. In addition to that, if the cut-off value was calculated, this value was estimated 2.48. Sensitivity and specificity for this value were $\% 60.8$ and $\% 58.8$. In some cases, this cut-off value could also be rounded to 2.5 to make it easier for interpretation. In this case, the sensitivity and the specificity ratios were $\% 59.7$ and $\% 59$ respectively (Table 6, 7) (Figure 3). Platelet to lymphocyte ratio (PLR) value as well as NLR were also used in studies. The results indicated that there was not any superiority between these values even if it was examined group by group.

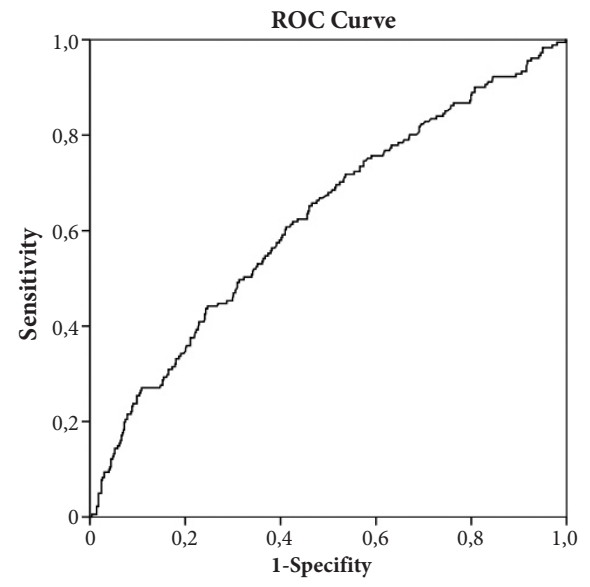

Figur 3. NLR ROC analysis

Table 6: NLR cut off values according to 2,48

\begin{tabular}{llllll} 
& BPH & & PCa & \multicolumn{2}{c}{ Number of patients } \\
\hline NLR $<2,48$ & 293 & & 71 & 364 & \\
NLR $\geq 2,48$ & 205 & & 110 & 315 & \\
Total & 498 & 181 & & 679 & \\
\hline NLR & Sensitivity & Specificity & PPV & NPV & Kappa \\
\hline NLR $-\mathbf{2 , 4 8}$ & $\% 60,8$ & $\% 58,8$ & $\% 34,9$ & $\% 80,5$ & 0,159 \\
\hline
\end{tabular}

PPV: Positive predictive value NPV: Negative predictive value

Table 7: NLR cut off values according to 2,50

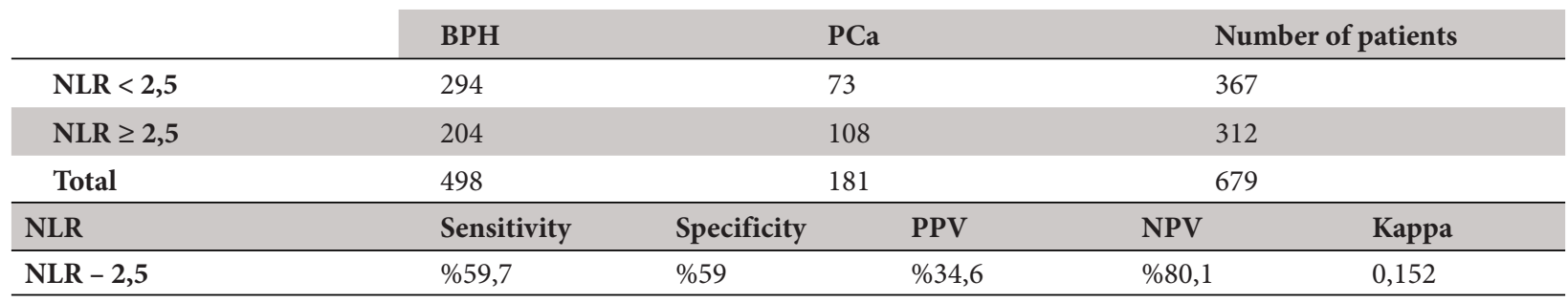

PPV: Positive predictive value NPV: Negative predictive value

AUC in ROC analyses were found 0.624 in NLR versus 0.646 in PLR and the appropriate number of cut off value for PLR was 120 (Figure 4) (Table 8, 9). Digital rectal examination (DRE) was included in prostate evaluation. In this study, DRE was significant in detecting prostate cancer in all groups. This level of significance was becoming more important with increasing PSA values (Table 10) (Figure 5). In addition, bone scintigraphy was evaluated in 52 patients in group four. 31 of these 52 patients (\%59.7) had bone metastases but 21 (\%40.3) of them had no pathological involvement in bone scintigraphy.

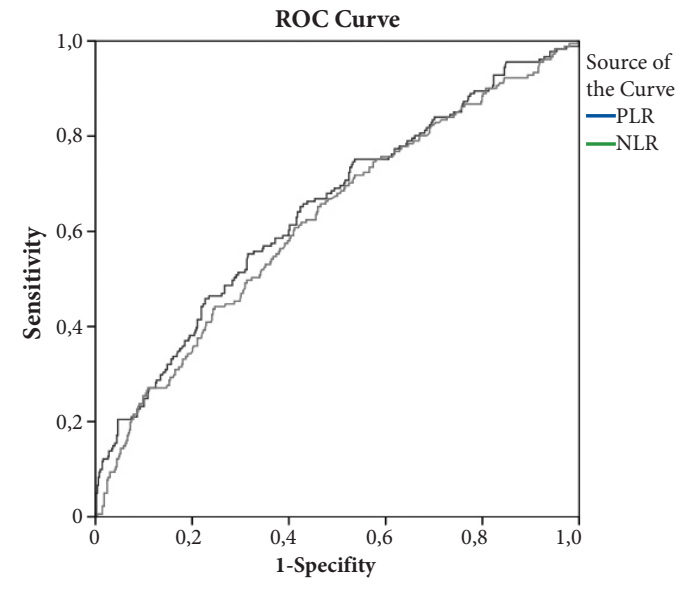

Figur 4. NLR against to PLR ROC curve analysis 
Table 8: PLR cut off values according to 120

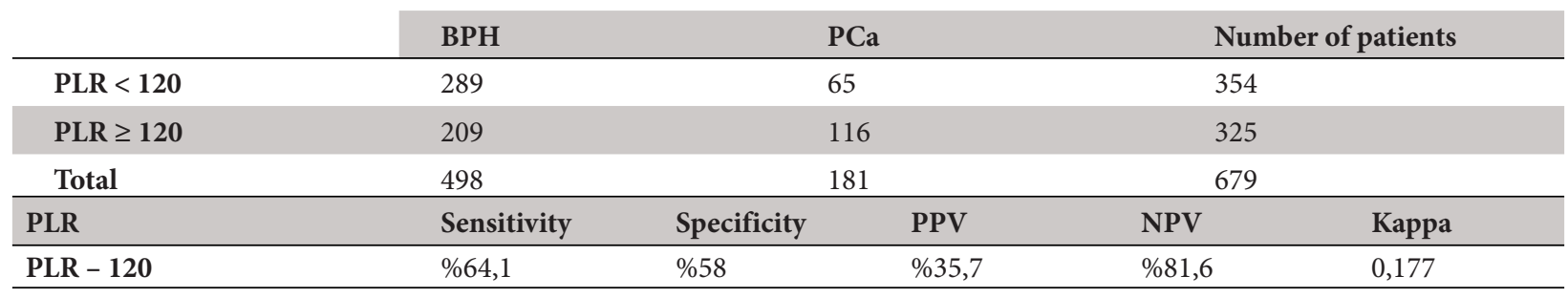

PPV: Positive predictive value NPV: Negative predictive value

Table 9: NLR and PLR's AUC values

\begin{tabular}{lll} 
& NLR - AUC & PLR - AUC \\
\hline PSA 2.5-4 & 0.410 & 0.488 \\
PSA 4-10 & 0.575 & 0.603 \\
PSA 10-20 & 0.632 & 0.664 \\
PSA 20+ & 0.644 & 0.680 \\
Total & 0.624 & 0.646 \\
\hline
\end{tabular}

PPV: Positive predictive value NPV: Negative predictive value

Table 10: Digital rectal examination (DRE) in $\mathrm{BPH}$ an $\mathrm{PCa}$

\begin{tabular}{|c|c|c|c|c|c|c|}
\hline Group & & \multirow{2}{*}{$\frac{\mathrm{BPH}}{63}$} & \multicolumn{2}{|l|}{ PCa } & \multicolumn{2}{|l|}{ Total } \\
\hline \multirow{3}{*}{$\begin{array}{l}\text { PSA levels } \\
2,5-4\end{array}$} & DRE negative & & & & 69 & \\
\hline & DRE positive & 0 & \multicolumn{2}{|l|}{2} & \multicolumn{2}{|l|}{2} \\
\hline & Total & 63 & \multicolumn{2}{|l|}{8} & \multicolumn{2}{|l|}{71} \\
\hline \multirow{3}{*}{$\begin{array}{l}\text { PSA levels } \\
4-10\end{array}$} & DRE negative & 344 & \multicolumn{2}{|l|}{43} & \multicolumn{2}{|l|}{387} \\
\hline & DRE positive & 0 & \multicolumn{2}{|l|}{37} & \multicolumn{2}{|l|}{37} \\
\hline & Total & 344 & \multicolumn{2}{|l|}{80} & \multicolumn{2}{|l|}{424} \\
\hline \multirow{3}{*}{$\begin{array}{l}\text { PSA levels } \\
10-20\end{array}$} & DRE negative & 69 & \multicolumn{2}{|l|}{5} & \multicolumn{2}{|l|}{74} \\
\hline & DRE positive & 0 & \multicolumn{2}{|l|}{25} & \multicolumn{2}{|l|}{25} \\
\hline & Total & 69 & 30 & & 109 & \\
\hline PSA levels & DRE negative & 22 & 2 & & 24 & \\
\hline & DRE positive & 0 & 61 & & 61 & \\
\hline & Total & 22 & 63 & & 85 & \\
\hline All group & DRE negative & 498 & 56 & & 554 & \\
\hline & DRE positive & 0 & 125 & & 125 & \\
\hline & Total & 498 & 181 & & 679 & \\
\hline PSA groups & Sensitivity & Specificity & PPV & NPV & & Kappa \\
\hline PSA 2,5-4 & $\% 25$ & $\% 100$ & $\% 100$ & $\% 91,3$ & & 0,372 \\
\hline PSA 4-10 & $\% 46,2$ & $\% 100$ & $\% 100$ & $\% 88,9$ & & 0,583 \\
\hline PSA 10-20 & $\% 83,3$ & $\% 100$ & $\% 100$ & $\% 93,2$ & & 0,875 \\
\hline PSA 20+ & $\% 96,8$ & $\% 100$ & $\% 100$ & $\% 91,7$ & & 0,940 \\
\hline Total & $\% 69,1$ & $\% 100$ & $\% 100$ & $\% 89,9$ & & 0,766 \\
\hline
\end{tabular}

PPV: Positive predictive value NPV: Negative predictive value 
Graphic 1. Digital rectal examination (DRE) accuracy measures

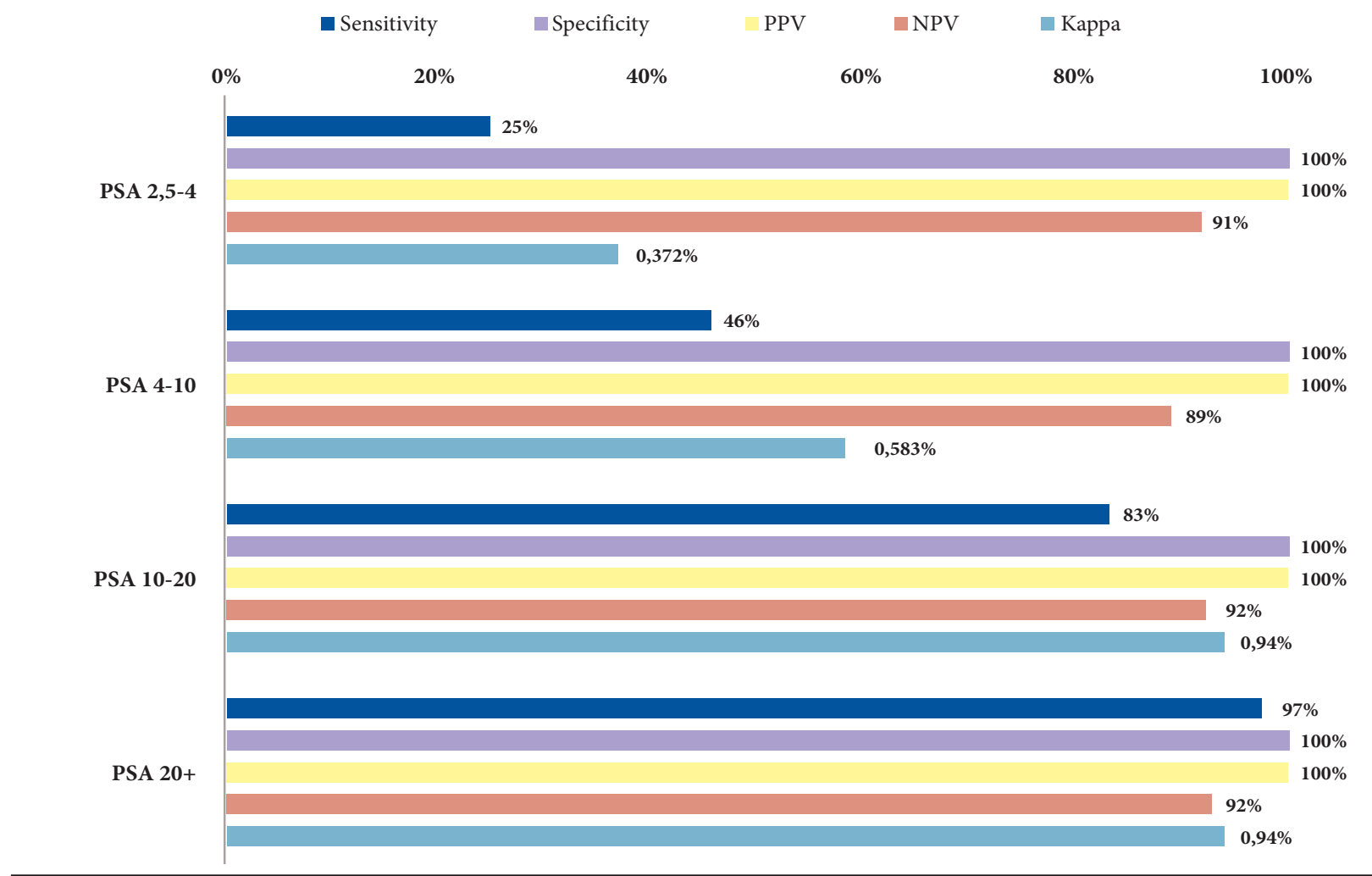

PPV: Positive predictive value NPV: Negative predictive value

No statistically significance was found in the ROC curve analysis to evaluate the safety of NLR foreseeing bone metastasis (Figure 6).

Only PSA and PSA densities were observed in the

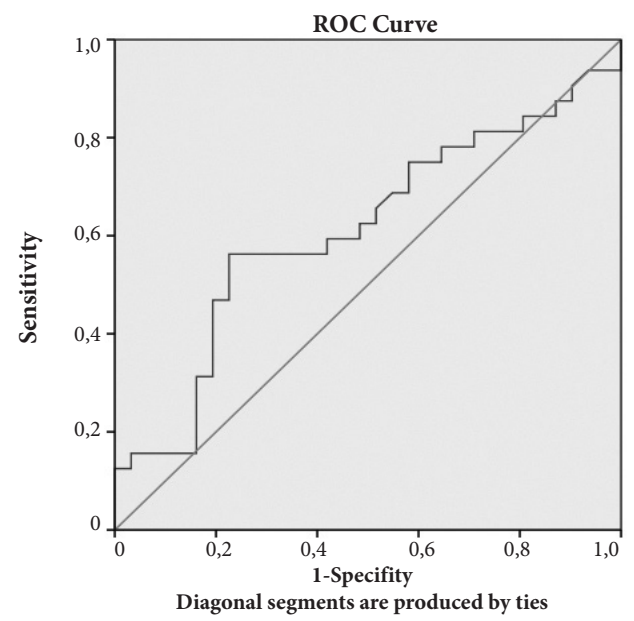

Figur 6. Statistical ROC curve of bone scintigraphy-metastasis relationship for patients with PSA 20 and above. measured properties with scintigraphy result. Other parameters were not related to scintigraphy positivity. The AUC number for PSA and PSA density was 0,785 and 0,750. (Figure 7) (Table 11,12)

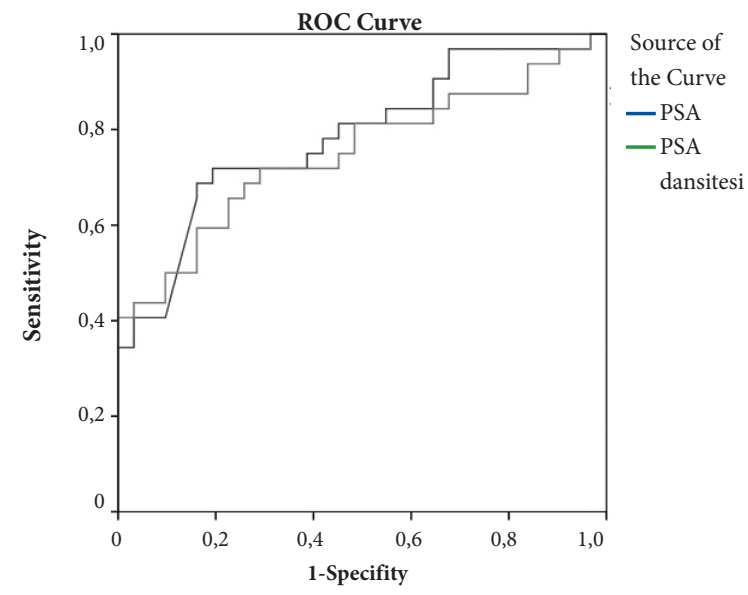

Figur 7. PSA and PSA density relations with sintigraphy in ROC curve analysis 
Table 11: PSA relationship with scintigraphy

\begin{tabular}{|c|c|c|c|c|c|}
\hline & Metastasis (-) & & Metastasis (+) & \multicolumn{2}{|c|}{ Number of patients } \\
\hline PSA $<75$ & 25 & & 9 & & \\
\hline PSA $\geq 75$ & 6 & & 23 & & \\
\hline Total & 31 & & 32 & & \\
\hline PSA & Sensitivity & Specificity & PPV & NPV & Kappa \\
\hline PSA - 75 & $\% 71,9$ & $\% 80,6$ & $\% 79,3$ & $\% 73,5$ & 0,524 \\
\hline
\end{tabular}

PPV: Positive predictive value NPV: Negative predictive value

Table 1: PSA density relationship with scintigraphy

\begin{tabular}{|c|c|c|c|c|c|}
\hline & Metastasis (-) & & Metastasis (+) & \multicolumn{2}{|c|}{ Total } \\
\hline PSA density $<1.6$ & 23 & & 11 & \multicolumn{2}{|c|}{34} \\
\hline PSA density $\geq 1.6$ & 8 & & 21 & \multicolumn{2}{|c|}{29} \\
\hline Total & 31 & & 32 & \multicolumn{2}{|c|}{63} \\
\hline PSA & Sensitivity & Specificity & PPV & NPV & Kappa \\
\hline PSA - 75 & $\% 65,6$ & $\% 74,2$ & $\% 72,4$ & $\% 67,6$ & 0,398 \\
\hline
\end{tabular}

PPV: Positive predictive value NPV: Negative predictive value

\section{DISCUSSION}

Nowadays despite advances in imaging modalities, prostate biopsy under TRUS guidance still remains the gold standard for diagnosis of PCa. High PSA level is the most commonly used indication for prostate biopsy under TRUS guidance. (4) Since the definition of PSA, in various retrospective and prospective studies; PSA and PSA variants were evaluated to distinguish benign conditions and PCa. Particularly, free/total PSA ratio is used between the PSA levels of $4-10 \mathrm{ng} / \mathrm{ml}$ and when it is defined "gray zone". (5) In this study our patients in group 1 were PCa \%11.3 of all. At the same time these ratios are \% 18.9 for group 2, \%33 for group 3 and $\% 74.1$ for group 4 . These datas show that although PSA is the best marker in cancer screening, we can provide to detect malignity by using another biomarkers: one of them is NLR. Several studies have shown that prostatic inflammation is implicated in PCa etiology and that it plays a role in prostate carcinogenesis through chronic inflammation, impaired immune response, and regulation of the tumor microenvironment. (6) In addition, increasingly indirect evidence suggests that NLR can be simple marker of systemic inflammatory response, it has been shown to be an independent marker for some solid malignancies, including prostate cancer. (7) It is enthusiastic to use NLR to find prostate cancer in first biopsy or suspecting malignancy although patology result is benign. When PSA is more than $4 \mathrm{ng} /$ $\mathrm{ml}$, NLR cut off value is statistically significant in diagnosis of $\mathrm{PCa}$ which makes it promising in polyclinic assesments. With the recent advances in technology clinicians give their attention to multiparametric MRI in detecting prostate cancer, NLR is cheaper and there is no need of any kit.

Total PSA is used in prostate cancer screening. Prostate volumes of patients are in a wide range in human body that's why PSA density is more specific to detect PCa. Therefore, instead of total PSA in cancer screening, it seems more rational to use personal data like PSA density. Nordström et al find close results about PSA density and think it might inform biopsy decisions and spare some men from the morbidity associated with a prostate biopsy. (8)

We did not find strong correlation between NLR, Gleason score and biopsy percentage but there was a strong correlation between Gleason score and tumor percentage in biopsy cores. We think that it would be more accurate to look at other studies and decide on the results of meta-analysis. In addition to that, there are some studies that support our results, one of them is Gökçe et al. They reported that NLR is associated with high Gleason scores in PCa patients. (9) 
Although many studies mention that NLR is important in diagnosis, generally no cut off value is given. As a result of our analysis, we determined the cut off value as 2.5. Kawahara et all found the cut off value as 2.40 and AUC in ROC analysis 0.582. (10) These parameters were slightly lower than the obtained results in this study however they are really close to each other.

PLR is one of the most popular parameters recently in peripheral blood count as well as NLR. When we analyzed the results, we found very close results. Especially in ROC analysis, the AUC value was almost the same. The obtained cut-off value from this study also supported the literature. Yuksel et al found the cut off value is 110 against to our value is 120 . (11)

Developing technology makes many contributions to physicians in both imaging and laboratory. Although this provides many advantages, it decreases the rate of physical examinations performed to the patients day by day. According to our findings, DRE is significant in all groups. Meta-analysis studies support these findings. (12)

Although NLR has a diagnostic value, we found that it was insufficient for bone metastasis in prostate cancer. Perhaps in larger series of studies it may have a different result. It is quite difficult for NLR to replace imaging methods such as bone scintigraphy.

If we criticize ourselves as a result, the most crucial limitation of our work is retrospective. Our patients have high PSA levels and we have not any control groups. We hope that lots of prospective randomized controlled trials are needed in this topic.

\section{CONCLUSION}

The NLR in peripheral blood sample is a cheap parameter that can be easily calculated. We concluded that the predictive value of NLR in PCa is fairly well in patients with a PSA level above $4 \mathrm{ng} / \mathrm{ml}$. Besides being a parameter that can support PSA, it is a biomarker that may be useful for patients who need further examination in gray zone patients.

\section{ACKNOWLEDGEMENT}

We would like to thank our nurses Cavus, $\mathrm{N}$ and Yildirim, $\mathrm{M}$ for their assistance.

\section{REFERENCES}

1. Siegel R, Ma J, Zou Z, et al: Cancer statistics, 2014. CA Cancer J Clin 2014; 64: 9-29.

2. Ruijter E, van de Kaa C, Miller G, et al.: Molecular genetics and epidemiology of prostate carcinoma. Endocr Rev 20 (1)pp:22-45.

3. Sundar S, O'Cathail M. Neutrophil-lymphocyte ratio is prognostic butnot predictive of response to Abiraterone in metastatic castrationresistantprostate cancer. JRSM Open.2015 Nov3;6(12):2054270415611332

4. Huang TB, Mao SY, Lu SM et al. Predictive value of neutrophil-to-lymphocyteratio in diagnosis of prostate cancer among men who under went template-guided prostate biopsy: A STROBE-compliant study. Medicine (Baltimore) 2016;95:e5307.

5. Erol B, Gulpinar MT, Bozdogan G et al. The cutoff level of free/total prostate specific antigen (f/t PSA) ratios in the diagnosis of prostate cancer: A validation study on a Turkish patient population in different age categories. Kaohsiung J Med Sci 2014;30:545-50.

6. Taverna G, Pedretti E, DiCaro G, et al. Inflammation and prostate cancer: friendsorfoe? InflammRes 2015;64:27586.

7. Fujita K, Imamura R, Tanigawa G, et al: Low serum neutrophil count predicts a positive prostate biopsy. Prostate Cancer Prostatic Dis 2012;15:386-390.

8. Nordström, T., Akre, O., Aly, M., Grönberg, H., \& Eklund, M. Prostate-specific antigen (PSA) density in the diagnostic algorithm of prostate cancer. Prostate Cancer and Prostatic Diseases 2017;21,57-63

9. Gokce MI, Hamidi N, Suer E, et al. Evaluation of neutrophil-to lymphocyte ratio prior to prostate biopsy to predict biopsy histology: results of 1836 patients. Can Urol Assoc J 2015;9:E761-5.

10. Kawahara T., Fukui S, Sakamaki K et al. Neutrophil-to-lymphocyte ratio predicts prostatic carcinoma in men undergoing needle biopsy. Oncotarget 2015Oct13;6:32169-76.

11. Yuksel OH, Urkmez A, Akan S, Yldirim C, Verit A. Predictive Value of the Platelet-To-Lymphocyte Ratio in Diagnosis of Prostate Cancer. Asian Pac J Cancer Prev 2015;16:6407-12.

12. Naji L., Randhawa H, Sohani Z. et al. Digital Rectal Examination for Prostate Cancer Screening in Primary Care: A Systematic Review and Meta-Analysis. Ann Fam Med 2018;16:149-154. 